\title{
The Ontology of Resistance: Power, Tactics and Making Do in the Vila Rubim Market
}

\author{
A.d.P. Carrieri, D. Papadopoulos, E.A. Quaresma Jr, \& A.R.L.d. Silva
}

\section{Urban Studies}

\begin{abstract}
The paper re-examines the relation between power and resistance by investigating the reconstruction of the Vila Rubim market, one of the established markets in the city of Vitória in Brazil. After a fire that destroyed large parts of the market - probably the most significant event in its history - the market had to be fully rebuilt and the broader local area had to be redeveloped. Empirical materials were collected through ethnographic fieldwork, interviews and visual and archival research. The destruction and reconstruction of the Vila Rubim market unleashed a fierce struggle between the city council and the market's traders. We argue that the traders' resistance to urban management held the primacy in shaping the outcome of this conflict by initiating a multiplicity of space making practices. We reframe resistance as ontological, that is as the practice of creating a material position, of making a world that allows an alternative form of life to emerge beyond given power relations. Rather than in acts of protest, the stallholders of the Vila Rubim market engaged in mundane tactics which created alternative ontologies of existence in urban space.
\end{abstract}

\section{Keywords}

Ontological Organising, Primacy of Resistance, Tactics, Urban Space, Make Do, Management

The Mercado da Vila Rubim is one of the few established markets in the city of Vitória in Brazil. It was destroyed by a fire in 1994. The market had to be fully rebuilt and the broader local area redesigned. Its reconstruction lasted 13 years. During this period and similar to its beginnings, stallholders and shopkeepers were selling their goods in the adjacent streets rather in the market itself. This period is the focus of this paper. The fire was a turning point in the life of the market - a myriad of new urban management practices and new forms of resistance emerged after the destruction. The oppositional relation between the city council and the stallholders is articulated through urban space and its material, ontological remaking. It is a continuous struggle, in which ontological resistance, a key term that we will develop 
throughout this paper, occurs almost daily in and around the market.

We use the term ontological resistance to describe everyday political practices that rather than focussing solely on traditional representational politics, engage directly in the remaking of the material fabric of urban environments. Ontology here denotes that such everyday politics operate within the constraints of given material spaces and that its primary starting point is the transformation of the immediate material conditions of everyday existence. Alternative food growing practices, citizen science, urban gardens, squatting and repurposing, the caretaking of local ecological systems, community technoscience, alternative and traditional knowledge systems, the creation of DIY technologies, making, mending, repairing and hacking are examples of such ontological practices that are often connected to politics of resistance. The paper explores such politics in relation to urban space and argues that direct interventions in the material order of the urban environment can be a powerful tool in the articulation of contemporary politics of resistance that often drives how urban conflicts unfold.

We engage with concepts developed in the works of Foucault, de Certeau and Deleuze to create a theoretical vocabulary that captures how alternative material practices, ontological organising as we will call it, give birth to everyday worlds of existence that come to challenge established power relations. We start with Foucault's thesis on the primacy of resistance and his elusive claim that resistance comes first (section 1). We discuss these ideas with a specific focus on how resistance unfolds and erupts within the realm of mundane urban life. de Certeau's concept of tactics provides a useful framework for translating the primacy of resistance to an everyday practice (section 2). In a third theoretical step we deploy the work of Deleuze to reframe tactics as a practice that reconfigures the ontological fabric of mundane urban life, something that we develop conceptually as ontological organizing (section 3). It is important to note here that our main focus is not on these three theories as such but on the attempt to assemble a conceptual framework for understanding ontological resistance in the case of the Vila Rubim market.

In the sections that follow we present and analyse the empirical materials that we have collected through our fieldwork on the history of the Vila Rubim market: we start with a discussion of how the market has evolved since its beginning (section 4), the events of the its destruction in 1994 (section 5) and the subsequent conflict between the stallholders and city management over its redevelopment (section 6). We then come to discuss how ontological organizing unfolded through different cycles of conflict that erupted during this process (sections 7-9). In the final concluding sections of the paper we discuss the world making capacities of ontological organising and reframe resistance as a form of politics that does not 
primarily make claims directly to power but changes the underlying material conditions by which power operates (section 10). Ontological resistance is about creating many minor alternative worlds within urban space and it is here that we see the implications of this form of organising for rethinking and practising resistance in a way that could potentially enhance its efficacy in today's tumultuous urban life (section 11).

\section{The primacy of resistance in urban space}

Although there is significant scholarship on the emergence of non-oppositional ontologies, affective geographies and their complex material configurations (Braun, 2008; Clark, 2011; Tolia-Kelly, 2006; de Vries and Rosenow, 2015), there is less exploration of what this really means for an everyday politics of resistance within urban space. This paper approaches this question through an empirical case study by simultaneously advancing a theoretical discussion of resistance driven by the work of de Certeau and Deleuze. Here we conceptualise resistance as the creation of everyday material alternatives, an approach that stands against 'standard definitions of resistance within geography, which identify it as the resisting of domination or oppression, building on well-established political movements' (Legg, 2018: 28).

Such a conceptualisation of resistance starts with problematizing dominant interpretations of Foucault's analysis (1978) of power and resistance which assume the existence of a merely coercive power and treats resistance as a mere reaction to it. Such an approach to power and resistance has shaped our understanding of conflict in urban space: see, for example, Ju and Tang (2010) on grassroots environmental groups against the South Korea government, Lauermann and Vogelpohl (2019) on protest campaigns against the organisation of mega-events in Boston and Hamburg, Davies and Blanco (2017) on contentious antiausterity politics, Pearsall (2013) on anti-gentrification struggles in New York or work describing different modes of resistance to surveillance (Swanlund and Schuurman, 2019; Grommé, 2016). Although this work is important and, indeed, necessary for understanding and visualising oppositional politics, it has been also problematized because it 'draws a strict contrast between the diabolic world of power and the liberating world of resistance' (Fleming and Spicer, 2008: 304).

The second line of interpretation of Foucault's work states that there is no real division of power and resistance and implies that ' $[\mathrm{t}]$ he operations of power, domination and resistance are seen as integrally rolled up in articulations of society and space, resulting in the entanglement of resisting and dominating practices' (Routledge, 2009: 647). Power and 
resistance are seen as indivisible, following Foucault's (1978: 95) mantra that wherever there is power there is also resistance. Resistance is always an inflection of power. Spinney (2010), for example, analyses urban cycling and argues that practices which have been widely seen as a performance of resistance are a performance of a power that is always retransforming and reshaping local actions.

It is from this second line of interpretation that our discussion of the dynamics of power and resistance in urban space starts. de Certeau (1984) provides us with valuable help for understanding relations of power in this context: strategies seek to prevent the tactics that attempt to appropriate the city and its meanings by those who move beyond acceptable limits. Strategies act upon the actions of such individuals or groups attempting to transform their everyday modes of existence. And beyond that, Carrieri et al. (2009) have shown in their discussion of the introduction of citizens' disciplining programmes in Belo Horizonte through the city's 'Code of Postures' and the 'Centro Vivo' that strategic actions not only attempt to direct the everyday actions of people but also to shape the coordinates in which potential resistance can take place (see also Carrieri and Murta, 2011). de Certeau (1984: xix) defines strategy as 'the calculus of force-relationships which becomes possible when a subject of will and power (a proprietor, an enterprise, a city, a scientific institution) can be isolated from an "environment." A strategy assumes a place that can be circumscribed as proper (propre) and thus serve as the basis for generating relations with an exterior distinct from it.'

This interplay between power/strategy and resistance/tactics seems to be able to reveal the mechanics of city governance and how urban space is made (Foucault, 1980: 149). From this point of view, urban space is organized through strategic practices that respond and subsequently provoke the tactics of its inhabitants. And this is the reason why the second line of interpretation mentioned earlier appears to be plausible and is so widespread: power and resistance are conceived as inseparable, each one responds to the other in an eternal linear succession of strategies and tactics.

But to what extent is this the case? What if we consider resistance as the outside of an existing order of power relations (Deleuze, 2006) that drives transformation and changes its very configuration? What if resistance has the primacy and tactics shape strategy? The starting point of this approach can be still found in Foucault's work. He miraculously says that '[i]f if there was no resistance, there would be no power relations. Because it would simply be a matter of obedience. You have to use power relations to refer to the situation where you're not doing what you want. So resistance comes first, and resistance remains superior to the forces of the process; power relations are obliged to change with the resistance. So I think that resistance is 
the main word, the key word, in this dynamic' (Foucault, 1997: 167).

In this last turning point, Foucault assigns to power the ability to define the structure of social action and potentially shape how future actions will be articulated. But paradoxically this capacity of power relations to structure social action is not driven by power itself but by resistance (Checchi, 2014). This paper advances this argument, namely that resistance does not reshape power when it directly opposes it but when it creates alternatives that escapes it. How can we evade power relations in order to materialise transformative resistance? How can this be done within urban space?

\section{Evading city management: Tactics of resistance}

Urban space is permeated by divergent discourses and practices capable of managing transactions that daily construct it. One of the most prominent of these discourses is urban management and planning (Limena, 2001). Urban management is generative in its nature: it gives birth to a multiplicity of other practices that vary enormously, from discourses about where certain businesses can and cannot be located (Parker, 2011) or debates on how to accommodate citizen disagreement (Özdemir and Tasan-Kok, 2017) to the management of movements of people (King, 2010), to tightly linking areas of cities to specific activities (Carrieri et al., 2009; Carrieri and Murta, 2011), and so on. Urban planning and its actors can be associated with what de Certeau (1984) considers as a practice of a 'subject with will and power' who incites individuals or social groups to specific forms of behaviour and ways of acting. Nonetheless, an actor with power does not mean that it owns the power it possess-see an example in Wideman and Masuda (2018) on strategic government interventions of the city council of Vancouver (see also Williams et al., 2012). Such social actors, we could say with Deleuze (2006: 75), 'are not sources or essences, and have neither essence nor interiority. They are practices or operating mechanisms which do not explain power, since they presuppose its relations and are content to "fix" them, as part of a function that is not productive but reproductive.'

When seen only from the perspective of strategy, urban space appears to be managed by the 'powerful' and marked by injustice (Williams, 2016). From this point of view the relationship of power and resistance remains trapped, as discussed earlier, in an eternal dialectic and complicity: power tries to fix resistance 'in the diagram,' as Deleuze would have said, and resistance tries to confront power. When we talk about resistance as confrontation to power then we propose to talk about protest, opposition, or revolt. In this configuration, power and 
'resistance' (as protest, opposition, or revolt) are in tight and infrangible connection, one opposing the other. In fact, one could say that 'resistance' as opposition becomes part of fixed relations and enters the nexus of existing order of forces-Checchi (2015) provides an insightful analysis of these different readings and meanings of resistance in his work on Foucault.

However, in this paper we try to conceptualise resistance in a different way: as 'local, unstable and diffuse', as something that does not emerge in direct relation to power and does not 'emanate from a central point or unique locus of sovereignty' (Deleuze, 2006: 73). Resistance here is not what opposes power but what exits power by creating a locus that exists outside of existing power relations. If Deleuze (2006: 75) argues that 'there is no state, only state control, and the same holds for all other cases' then in a similar manner we can say that there is no city but urban management and the same applies to all other organizations within. When institutions are seen as open forms of practices, power and resistance are no longer just in a tight inseparable relation because none of them simply 'owns' the power over the other. As we will show later in our case study there are no stallholders against the city council and when the former act in ways that cannot be predicted, expected or calculated by the city management, their actions emanate from outside of the existing order of power relations within the city.

With de Certeau we can call these actions 'tactics'. What characterises tactics is not that it opposes strategy's plans but that it subtracts itself from the locus of strategy. 'I call a "tactic" [...] a calculus which cannot count on a "proper" (a spatial or institutional localization), nor thus on a border-line distinguishing the other as a visible totality. The place of a tactic belongs to the other. [...] The "proper" is a victory of space over time. On the contrary, because it does not have a place, a tactic depends on time- it is always on the watch for opportunities that must be seized "on the wing"' (de Certeau, 1984: xix).

Tactics are tricks for evading the fixed order of power relations. Tactics survive not because they confront power but because they use cunning to escape from it (Smith et al., 2015; Papadopoulos et al., 2008). Tactics open continuously new ways of existence, create new worlds. 'Power' has to follow and recapture these spaces. It is in this sense that tactics exemplify the primacy of resistance that we mentioned earlier: Tactics, as resistance, can be conceived as an creative force which cannot be explained by the given order of power fixed by strategy but introduces new unexpected ways of acting. Tactics interrupt the generativity of urban management and create new 'organizational ontologies.'

\section{Making do and the organizational ontology of tactics}


If strategy lies within the existing order of forces, tactics are 'multiform, resistance, tricky and stubborn procedures that elude discipline' (de Certeau, 1984: 96). de Certeau offers a glimpse on these everyday actions that are characterised by the art of 'making do': by showing how people find in their daily activities ways to overcome prescriptions using ingredients that can be found within fixed power relations; by carrying out 'coups' that are disguised in particular forms of reading, making, walking, relating, speaking, cooking, selling or mundane organizing. Studies such as that of Pinder (2011) on walking, of Junquilho et al. (2012) on public schools, of Carrieri et al. (2019) on circuses, of Kokkinidis (2014) on workers' self-management or of Spinney (2010) on urban cycling show how the (re-)appropriation of power is founded on these micro-liberties that emerge as people engage in their everyday life 'since they lack their own space, have to get along in a network of already established forces and representations (for a discussion see Machado et al., 2017). People have to make do with what they have' (de Certeau, 1984: 18).

de Certeau here helps clarifying Foucault's cryptic assertion on the primacy of resistance mentioned earlier. Resistance and power operate with the same stuff of life but they are not in direct conflict. With the work of Deleuze (2006), Checchi (2015) and Papadopoulos et al. (2008) we propose to read resistance (that is resistance as resistance, not as opposition) as a movement of exit and escape of the prevalent power relations in a certain field. Resistance is here not about direct confrontation but about evading the conditions in which power relations operate by arranging the mundane conditions of existence in ways that allow for such an exit to take place. In order to facilitate such an escape a community needs to organize its material independence, food, shelter, care, access to resources, alternative forms of cooperation, suitable modes of exchange. The making do with what is available to the community in each certain moment in order to be able to resist is what we call organizational ontology, a term which we borrow here (Papadopoulos and Tsianos, 2013; Papadopoulos, 2018) to describe the practice of resisting power by organizing alternative forms of life: alterative ontologies.

In our use of the concept of ontology and materiality we rely on existing debates in anthropology (e.g. Holbraad et al., 2014), geography (e.g. Braun, 2008), urban studies (e.g. McFarlane, 2011; Williams, 2016), organization studies (e.g. Carlile et al., 2013; Silva and Silva, 2019), science and technology studies (e.g. Woolgar and Lezaun, 2013) and political theory (e.g. Braun and Whatmore, 2010). Although it is beyond the scope of the paper to engage with these very diverse debates directly, they inform our discussions of the term and the way we deploy it here. In particular, when we refer to ontology we mean the more-than-human 
capacity of certain actors (such as a group of humans or members of an animal species or certain objects etc) to change the material configuration of their concrete space of existence (Papadopoulos, 2018).

Within this framework, one needs to deconstruct the idea of a deliberate intention to remain outside an existing order of power because it reifies the existence of a centrally organized subject (vis-à-vis power). The inside and the outside loose gradually meaning as communities create alternative ontologies of existence. The subject of tactics is not collectively organized as such, that is as a proper subject. Rather it often acts without even articulating its own refusal of power. In this sense resistance is not just dissent or withdrawal from power as a symbolic act. Resistance is a practice of creating - literally, that is ontologically - a position, of making a world that allows an alternative form of existence beyond given power to emerge (Whitson, 2007). When resistance is resistance (and not opposition, protest or revolt) it is with de Certeau the tactics of everyday life that destabilise power and change its fixed order.

\section{Vila Rubim market, before the fire}

The Mercado de Vila Rubim market in Vitória, Brazil was inaugurated in the homonymous neighbourhood in 1928. It is located in the centre of Vitória, the capital of the south-eastern state of Espírito Santo with a population of 327,000 (IBGE, 2010). The economy of the region is driven by mining, the steel industry, cellulose production and petrochemicals, all tightly linked to the ports of Vitória and the adjacent Tubarão. The economic wealth of the region is in stark contrast to the decline of Vitoria's inner city. A gentrification strategy was designed to address this issue by promoting historical heritage and transforming this widely 'demonized' area--including Vila Rubim and the market--to the guarantor of the cultural identity of Vitória (Botelho, 2005).

We investigated the history and development of the market and the surroundings through a multiplicity of qualitative methods since 2006. In the first phase of the ethnographic study, fieldwork in the market was carried out for three months, followed by a much longer engagement with the traders of fruit and vegetables produce. The materials collected from this research fed into an extensive field diary. Alongside fieldwork, written and photographic documents were collected from the Vila Rubim Traders Association (ACVR), from the Association of Stallholders of the Vila Rubim market, from the traders themselves and from the Municipal Public Archives and the State Public Archives. In the second phase of the study we continued fieldwork and conducted interviews with customers, suppliers and traders: 24 
stallholders (five fresh market dealers, five former traders and 14 belonging to other segments); five suppliers (three of fresh goods); nine customers; two representatives of associations; eleven employees; three police officers. In the current paper we will primarily focus on some of the visual materials underpinned by fieldnotes and interviews.

\section{Insert Figure 1}

In the decades after the establishment of the market, traders occupied the space around its original 1928 building selling many different products at wooden stands often described by our interviewees as precarious and temporary. In 1969 the vendors who were trading with fresh fruit and vegetables were transferred to three new sheds (named on Figure 1 as 'Galpão 1' and 'Galpões 2 and 3') very close to the market's original building. In 1970 an area around these new sheds was given also to traders who worked in the original building selling other types of products. This made the demolition of the original building possible and allowed the construction of an open public space, which was named as the 'Manoel Rosindo square'. The city council prohibited its use for selling products. But this would not last long: 'We organized a meeting. There, I said this: "Let's break into that square there. The beggars are there, we kick them out and occupy the place." Everybody was there. Each one took a stall [...] it happened through three invasions. ' (Interview E14, 55).

This episode led the Manoel Rosindo square to be commonly called 'Praça da Feirinha'/'Market Square'. The installation of makeshift booths and the somehow disorderly use of the square as a market continued until the 1990s as we can see in Figure 2. There are people waiting for the bus very close to the fresh food market stalls. The transient stalls of the vendors changed the material formation and use of the square permanently. This happened without any formal negotiation. Instead of opposing and challenging formally the city council's decision to keep the square free of trading, stallholders gradually occupied the space. Instead of opposition we see the silent introduction of the ontological and a-subjective tactics of everyday life.

\section{Insert Figure 2}

'The stallholders' as an actor was not formed as a socio-political subject before the invasion of the square. In fact, this subject doesn't exist as such. In tactics, subjects and their organizational ontologies do not exist before their transformative practices of urban space. In other words, subjects exist to the extent that they materially change space. There was not a 
collective subject of 'The Traders of Manoel Rosindo Square' before the square was occupied. It formed after the event: 'There was a moment when the mayor gave us 24 hours to get out. Then everybody met: "What are we going to do? We received a notice to leave." [...] We sought a local politician of that time. We explained the situation to him, and he said this: "Oh! Form an Association."[...] Then we went to court. It is there for 12 years now' (Interview E14, 51).

And even after the event the presence of such a subject was rather transient. It existed in the form of an association, but the association itself was not the locus of transformative action. It was occasionally mobilised in negotiations with urban management but action was gravitating primarily around the mundane practices of the a-subjective community of the stallholders trying to make do with the existing conditions in Vila Rubim. It is important to emphasize here that when we refer to the 'the stallholders' throughout this paper we do not mean a formally and coherently organized social group or a unitary and distinctive collective subject. We rather refer to a multiplicity of actors that forms a community of action as long as it engages in transformative ontological organizing. Such actor appears at certain moments as a powerful and seemingly solid and unified subject but it is in fact a very diverse, occasionally ambiguous and internally differentiated community that coheres around its participation in the making of a specific form of life.

Thus, there was neither a 'subject' that took over the square at once by decision nor did it take over the square entirely and permanently. Rather, the becoming a 'subjectivity' of the stallholders unfolds as they remake the square through a series of mundane material transformations and form gradually a fluid community of common experience and action (Stephenson and Papadopoulos, 2006). Sidewalks change their function as stallholders set up boxes of products and umbrellas to increase shadows for their goods and clients. Some of these makeshift stalls become semi-permanent changing the conditions of visibility and movement of the square. Bricks, stones, wooden planks, corrugated metal, fabric, pieces of plastic. Traffic around the square changes, more people passing and stopping, cars parking, noise, occasional shouting, honking, other sounds and smells. The use of the inner part of the square behind the stalls changes too, to accommodate people who use it to sustain a life on it rather than just visiting it recreationally. As the vendors make do with the materiality of the space there is available in order to extend the occupation of the square, they 'constantly manipulate events in order to turn them into "opportunities"” as de Certeau says (Silva and Silva, 2019). Day by day, year by year, square meter by square meter. In this process their subjectivity as "the stallholders of Vila Rubim" adapts and transforms to their practices and to the creation of their alternative material conditions of existence. Rather than through the formation of a clear-cut social subject, 
it is through time and materiality that tactics transforms space. This is the cunning of tactics.

\section{The explosion}

In the meantime, the precarious status quo of those who were selling their products in the three main sheds built in 1969 changed unexpectedly in a tragic way. In a moment in which the Vila Rubim market seemed to have found a relatively stable arrangement of its permanently transient and shifting existence a violent event changed its very material configuration. The tactics of the traders have taken advantage of several inconsistencies in the regulations of urban management and its incapacity to enforce these regulations: they perverted the strategies that defined what could or could not be sold. The initial planning was that only fresh produce should be sold in the sheds. Gradually though, several other goods were traded in the market, including fireworks. This led to a situation which became a neuralgic point in the relationship between the traders' tactics and the strategy of urban management: in July 1994 a fire destroyed much of the market. This event is often called 'the explosion' by many of our interviewees.

\section{Insert Figure 3}

In Figure 3, we can see what happened after the explosion of the fireworks stored on the site. Half of the long shed and shops disappeared along with much of two parts of the main building. Our conversations with stallholders reveal that it is important to realize that the issue here is whether there should have been fireworks on the site or not. The urban management's effort to 'fix' the everyday life of the market in a stable order and to impose clear-cut rules (for example by controlling which commodities should be traded and which not) is irrelevant from the perspective of people who are making do with what is available (Correia et al., 2018). The organizational ontologies and the tactics of the stallholders eluded strategy as they tried to support themselves and their families and to sustain their existence day by day. Fireworks - as well as the existence of many other commodities that we do not know of - was a minor part of these tactics, one though which changed the life of the market entirely. And although the explosion destroyed the market, one could say that the fireworks where immanent to it. An ethical judgement is inappropriate here. The stallholders respected the necessities of their own everyday conditions of existence. They had to make do in order to be able to continue to make a life. 


\section{The primacy of ontological resistance: Occupy and transform}

After the explosion urban management designated a place where the traders could resume selling their products. The shops that housed the old market vendors were almost completely destroyed, in addition to sheds 2 and 3 (Galpões 2 and 3 of Figure 1), which were mainly used for the trade of fresh produce. The stallholders were allocated in booths built on Nair Silva Azevedo Avenue (see Figure 1), a nearby market area 200 meters away from the original sheds. However, according to our interviews, after a few months there was a further subversion of urban management by the stallholders: because the new designated space was isolated and sales decreased they returned to the destroyed market and they built new stalls to work offhand (as it can be seen for one small part of the market in Figure 4). 'When the explosion happened, I worked [...] there, near the petrol station. The government arranged that for us. We worked, more or less, for about 60 days. We saw that this wasn't the way to go. Then we went back to the street. [...] My shop was right here, but it was all blown up [...] everything was burned, but we made a little shed inside where we were before. Then, they removed us from there and built for us something provisional, until we return. This was the only way. The city council made a promise, we leave from here, to work there. When they did [the city council constructed the provisional sheds], we went back to the same location' (Interview E16, 48).

Instead of entering into a power struggle with the city council about the relocation of the market to Nair Silva Azevedo Avenue the traders simply returned to the original site. Instead of seeking an institutional conflict they organized themselves by reclaiming and reshaping the old market. They, in fact, subtracted themselves from a direct power confrontation and they gradually started materialising their position through the making of new stalls around the destroyed market.

\section{Insert Figure 4}

In the centre of Figure 4 is the cleared area that was previously occupied by sheds 2 and 3 and around them we can see some of the traders' improvised booths. On the top right of the lot it is possible to see a rooftop of shed 3 that housed 'Supermarket A' the only store that survived the explosion. Apart from 'Supermarket A' almost all of the rest of trading in the Vila Rubim market was done through the improvised ontological tactics of the stallholders as they went back to the area around the destroyed building. Nonetheless, strategy rises again as the city council approves a new management agreement and commits to rebuild the sheds. Meanwhile, traders 
were supposed to move from where they were to work in purpose build wooden huts erected by the city council just in front of the market.

The persistence of the vendors to evacuate the space of the Nair Silva Azevedo Avenue and to relocate their activities around the original site sets up the material constraints against which the city council made its decision. Resistance to the original decision of the city council drives change and becomes a force for co-constructing urban space. Here we can see the meaning of the primacy of ontological resistance discussed earlier: firstly, resistance became the primary force of change because it did not confine itself to the coordinates that where defined by power (that is urban management's decision to relocate the traders to Nair Silva Azevedo Avenue). Secondly, resistance and the evasion of power wasn't just protest and opposition to the plans of city council; rather it become an ontological force, in the sense that it materialised through reclaiming the space around the market. The refusal of the traders took the form of an organisational ontology as a 'politics of matter' (Papadopoulos, 2014): by reshaping the space around the market, installing semi-permanent makeshift booths, transforming materially the surrounding streets and sidewalks, changing the flows of people and traffic, modulating the affective economy around the market, and, finally, by modifying the conditions of visibility. The tactics of the traders appear as an anti-discipline: a form of micro-liberty that holds the primacy over the strategy of the council. The primacy of ontological resistance in our case study means that it created a new practical and material space of existence that urban management could not neglect or bypass.

\section{From ontological organizing to representational politics and back}

The traders remained in their provisional stalls, eventually co-constructed by the city council, for several years. During that period, stallholders included a new political repertoire to their practices. In addition to the ontological tactics discussed so far they engaged also in formal representational politics. The first type of this politics focussed on activities that attempted to change the image of the stallholders and to connect to local instituted politics. Many of these political actions were performed by the Vila Rubim Traders Association but used by the traders as a whole, such as organising public meetings to express their political ideas, handing out promotional materials, distributing leaflets and hanging posters. The second set of political activities involved an intense engagement with the media which occurred in association with the commemoration of the anniversary of the explosion. The press was invited, the city council was also present, there were speeches and a cake was made specifically for the occasion. The 
media coverage was mobilised to expose to the public the failures of urban management in relation to the delay in the re-construction of the destroyed sheds.

The politics of representation inside existing power relations is very different to the politics of resistance as ontological tactics that we described in the previous sections. Our case study shows that they are not exclusive and in fact they often are part of the mobilisations of a certain community as the one described here. However, as much as representational politics was important in the actions of the community, we argue that such politics would not have much traction without the long ontological organizing that allowed the traders to materialiseliterally - alternatives to the one proposed by the city council. It is this materialisation that effectively facilitated the emergence of representational politics that in turn strengthened the collective actions of the stallholders and allowed them to create alliances within the neighbourhood and to expose and oppose the strategy of urban management on a formal political level.

We are used to recognise representational oppositional politics as the quintessential form of politics while here we argue that this politics is often impossible without the ontological tactics of resistance. Of course, ontological resistance might be not always the most appropriate tool for alternative political action. In certain cases representational politics or, indeed, other forms of politics and social movement action that aim to include alternative positions in mainstream instituted power might be necessary. Rather than elevating one type of politics to the centre of the practice of resistance we seek to oppose the implicit universalism of representational politics as the main pathway to politics and to open our sensibility to other forms of political practice that might be becoming increasingly pertinent for an effective performance of resistance in today's social and political conditions - for a further discussion see Tsianos et al. (2012); Papadopoulos (2018).

\section{The reconstruction of the market and the provisional dominance of urban management}

It is in this context and with much delay that the definite plans for the reconstruction of the destroyed sheds emerged. As the city council included the demolition of 'Supermarket A' (the only trading store that was not destroyed by the fire and was still operating in the market) a new struggle began when the owners opposed the council's plans. This conflict resulted in a court case that lasted until 2002, eight years after the fire. The impasse was resolved when the owner of 'Supermarket A' acquired a space just opposite of the destroyed sheds and built a new store there (see also Figure 1), thus withdrawing from the sheds and leaving them empty. 
Afterwards and when all legal issues were settled the city council carried out the reconstruction of the sheds according to a business plan which included the reinvention of the market's profile and activities and a reorientation towards tourism (Botelho, 2005). Since then, handicrafts began to be the predominant merchandise traded in the sheds. The new facilities include 38 stores and a mezzanine where public events can be performed. These plans initiated a new cycle of strategic and tactical actions.

This new cycle of conflict revolves around attempts to gentrify the broader neighbourhood (Butler, 2007). As in many other similar cases, one of the main drivers behind gentrification is the removal of portions of the population to less central or disputed areas of the city (Lees, 2012) and the maintenance of a specific social order (Uitermark et al., 2007). Economic interests dictated this decision and resulted in segregating those who were not classified as being able to sustain the new business development plan that was promoted by urban management. The plan for the Vila Rubim market was based on an urban planning blueprint that tried to introduce local craftsmen into a larger commercial area that should provide a new touristic hub gravitating around cultural and historic heritage.

In discussing the work of Foucault, Díaz (2012) states that prevalent rationalities of urban power are built to exclude the supposedly 'non-rational', that which is incomprehensible, everything that diverges. City management, as the bearer of legitimate institutional reason of urban planning, invented administrative practices that portrayed and classified the traders, the street peddlers, the working families of the local community, the invisible citizens of the neighbourhood as subjects that cannot support the new business plan and do not fit within the limits of what is reasonable in this new situation for development.

As in many other urban redevelopments (see for example a similar case in Belo Horizonte, Carrieri et al., 2009) also in the Vila Rubim market the attempt was to restrict, control, delimit the field of action of those who cannot be inserted into the new configuration of urban space. The new sheds resemble a small suburban shopping centre, with more ambient spaces and fewer stores (the more than 200 stalls that previously occupied the two sheds were reduced to only 38). This is similar to what de Certeau (1984) calls as a proper: a space victory over time. Only few of the traders who sold their goods in the booths in front of the sheds built by the city council during the previous cycle of resistance after the fire were selected and transferred to shops inside the sheds while the remaining booths were relocated by the city council to the Manoel Rosindo square, mentioned earlier. The stallholders accepted the transfer on the promise that the square would be also reconstructed and new permanent stalls made of brick would be built. It seems that the phase of reconstruction in the history of Vila Rubim was 
now dominated by urban management's strategies at the expense of the ontological tactics of the traders.

\section{The long duration of resistance}

With de Certeau (de Certeau, 1984: xix) we have argued earlier that tactics does not have a "proper place," that is a fixed and stable position from which it acts within a certain situation. This is reserved for strategy and power. The tactics of resistance rely on looking for the right moment for action in order to have a chance to be successful. Finding a window of opportunity extends the timeframe of resistance and extends its duration to include periods in which resistance might seem to be dormant or even inexistent. Ontological organizing depends on time in order to be able to transform existing ontologies outside the order of power. In the contrary, opposition, protest and revolt are space bound and they almost react instantly to power. Resistance has a long duration and can only unfold when the right moment is there.

The apparent dominance of strategy that we described in the precious section was only ephemeral. The stallholders waited, seemingly accepting the decision to expel them from Vila Rubim, and then at a certain moment they returned back. Silently but decisively. Figure 5 shows the return of fruit and vegetables stalls in front of the new reconstructed market.

Insert Figure 5

Once again the traders reclaimed the space of the market by-literally-remaking the spatial order of movement and visibility. Commonly used as an extension of the counter, the produce crates occupy a part of the sidewalk as before, allegorically and functionally, a practice that is, as ever before, prohibited by the city council. '[...] some time ago, the city council officer used to come to grab the tray, the stallholders used to go against him, to beat him, you understand [...]. Today this does not exist [the fights]. [...] The officer is passing by all the time, with the truck. [He says:] "Hey! If I arrive here tomorrow and those goods are here [pointing to the side walk], I do not want to know who is the owner, I will take it." [...] but here is like this: it is very difficult to sell goods that are inside [not presented on the sidewalk] [...], so we stop for two or three days, without putting anything outside. Then, you look around and there they are again: "Gee, one of the other guys put [the goods on the sidewalk]." [...]. "I'll put mine too." In a little while, about 15 days pass and the officer returns [...] and everyone gathers all [the goods] without any protest' (Interview E04, 52). 
Ontological resistance does not only change the materiality of public space and of people's movements in it, the shape of the streets around the market and how one walks but also the field of vision (Smith et al., 2015). People in cars or buses passing in front of the market are unable to see the small shopping centre that was the outcome of the restoration of the destroyed market sheds. Many of our interviewees said that after years of reconstruction the Vila Rubim market returned to the shape it had before the fire. This return reveals another implicit dimension of the temporality of ontological resistance. The future is not simply what lies ahead, because such future is often decided and executed by power and strategy. Rather, from the perspective of tactics the future means often to return back in order to reclaim the past in a different way within the present (Papadopoulos, 2018). Ontological resistance operates within the present but its duration is long and its movements often hybridise the linear temporal trajectories which power relies on.

\section{Between ontological tactics and symbolic power: Urban interspace}

Although the market survived many attacks on its existence over the course of several decades it finds itself today again in a very precarious situation. 'Here [the market] was like a bus terminal [...] So here was where one could change to other buses, the movement here was intense. Trade was very good, nowadays it does no longer exist. There are direct terminals there. [...] And everyone was shocked with this' (Interview E10, 46). There is a progressive abandonment of the central areas of the city towards its suburbs and the Vila Rubim market could become a victim of this urban transformation.

Throughout this paper we tried to describe how the traders of the market and their creative evasion of urban management became a force that literally contributed to the making of urban space. The ontological fabric of urban space is co-constructed; it is an interstitial field shaped by ontological resistance and urban management in a continuous process of transformation (Swyngedouw and Kaika, 2003). Urban space exists as interspace. Vila Rubim's whole history, especially since the 1960s, was made in these interstices between resistance and power: in the initial planning of the three sheds, each of the dozens of available stores should be occupied by one dealer of fruit and vegetables. However, many traders occupied more than a single space and began selling various products such as clothes, handicrafts, religious artefacts etc. By inserting new material configurations that silently defied council regulations the tactics of the traders created a precedence that has since then accompanied the market in all its developments, including of course the 1994 fire. 
In Figure 1 one can see how these ontological tactics established a different meaning of the Vila Rubim market: the reconstructed sheds 1, 2 and 3 between Rua Jair Andrade and Rua Orlando Rocha are formally considered as the Vila Rubim market according to the addresses and documents available at the city council. However, for people who work and come to shop or visit the market, Vila Rubim includes not only the sheds, but also all other stalls of Jair Andrade Street, the Manoel Rosindo Square, the adjacent supermarkets, groceries and shops and all other transient vendors of the area. This resilience of the ontological materialization of the meaning of Vila Rubim prevailed over attempts to delimit the symbolic and physical space of the market and to confine it to the actual space of the shopping mall. On the map in Figure 1 the Vila Rubim market corresponds to the light grey shaded area with a circumference of approximately 200 meters, a space which exceeds by far the actual space of the Vila Rubim market itself.

As King (2010) shows, urban management has power over the symbolic and representational processes that occur within city space. And although this power over the symbolic and the process of naming and classifying has the capacity to create spaces of exclusion and inclusion and to impose new forms of social order, ontological tactics have throughout Vila Rubim's history undermined the instalment of any fixed and final meaning of how specific parts of the area are called or what they are used for. Against power's rein over the symbolic the ontological tactics of the traders had constantly shifted the dominant meanings and made them permeable to other interpretations, other practices and other forms of existence (Silva and Silva, 2019). Meaning in urban interspace cannot be owned, at least not indefinitely by any actor. Meaning is constructed in the indeterminate and creative interspace of symbolic power and ontological resistance.

\section{Conclusion: Urban space making as world making}

Resistance happens when social practice materializes-literally, ontologically-alternatives which do not exist as such within the range of possibilities of strategy and power. This might sound contradictory but one has to consider, as Checchi (2014: 209) says, that ultimately 'resistance desires not to be recognized as such.' And exactly this is what happened several times in the history of the Vila Rubim market. Representation is never permanently fixed and meaning is never ultimately given by power. After all these years of reconstruction, Vila Rubim seemed to have returned to its past, to the times of makeshift wooden stalls, in contrast to the 'modern' commercial tourist hub that was supposed to become. 
Ultimately, the traders did not manage to reverse the plan for reconstructing the market as an open shopping area and as a tourist attraction. But they managed to reinsert themselves into these new conditions and to re-establish their livelihoods. Resistance in this case is not primarily about dialogue and even less about dialectics. Resistance (almost) never delivers a final and clear-cut resolution to a conflict. Rather, resistance in our case is about the subtraction from a conflict in order to create vitally divergent conditions of existence that cannot be avoided by power. It resembles the creation of 'forms of life' (Wittgenstein, 1958: 226) which cannot be bypassed or neglected. This is the reason that we have called the practices that establishes alternative forms of life ontological. Resistance creates ontological constraints to power: it changes power not by addressing it directly but by changing the material conditions by which power operates.

The target of ontological resistance is not power but world making. With Ranciere (1998: 42) we can say that '[p]olitics is not made up of power relationships; it is made up of relationships between worlds.' But here we need to take the meaning of 'world' literally and not metaphorically: as relationships between material worlds. When resistance is at stake, we make different worlds: alterontologies (Papadopoulos, 2018; Papadopoulos, 2011). The people who work and visit the Vila Rubim market know that the market encompasses-physically, affectively, materially, symbolically — an assemblage much more complex, large and openended than what the city council has planned (Farias, 2011).

In our analysis of the history of the Vila Rubim market we tried to uncover another type of resistance-ontological resistance-which is often less visible than common forms of protest, opposition and revolt that are addressed towards power. And although we think that universalising ontological resistance as a form of political practice is neither possible nor desirable, we would claim that perhaps it is the changing and troubling nature of today's social conflicts that allows us - and indeed obliges us - to invent alternative political practices such as ontological resistance. We therefore tried to generalise our case study to theory and to capture this practice within the conceptual framework of ontological organising, hoping that this might be a useful tool for approaching and practising such forms of resistance in diverse locations and geographies. Within this framework we tried to show that urban space is not the outcome of power antagonisms, clashing interests and struggles between less powerful and more powerful actors; urban space is the outcome of the practices of those who try to create their own minor worlds inside it.

\section{References}


Botelho TR (2005) Revitalização de centros urbanos no Brasil: uma análise comparativa das experiências de Vitória, Fortaleza e São Luís. EURE (Santiago) 31(93): 53-71.

Braun B (2008) Environmental issues: inventive life. Progress in Human Geography 32(5): 667-679.

Braun B and Whatmore S (2010) Political matter: technoscience, democracy, and public life. Minneapolis, MN: University of Minnesota Press.

Butler T (2007) For gentrification? Environment and Planning A 39: 162-181.

Carlile PR, Nicolini D, Langley A, et al. (2013) How matter matters: objects, artifacts, and materiality in organization studies. Oxford: Oxford University Press.

Carrieri AdP, Maranhão CMSdA and Murta IBD (2009) Crítica ao manejo humano em Belo Horizonte. Revista de Administração Pública 43: 1315-1342.

Carrieri AdP, Michelatto Natt ED and Aguiar ARC (2019) Brazilian canvas circuses: A field in constant motion and symbolic transformation. Revista de Administração da UFSM 12(2): 233-254.

Carrieri AdP and Murta IBD (2011) Cleaning up the City: A Study on the Removal of Street Vendors from Downtown Belo Horizonte, Brazil. Canadian Journal of Administrative Sciences / Revue Canadienne des Sciences de l'Administration 28(2): 217-225.

Checchi M (2014) Spotting the Primacy of Resistance in the Virtual Encounter of Foucault and Deleuze. Foucault Studies 18: 197-212.

Checchi M (2015) The Primacy of Resistance: A Historical and Conceptual Exploration. University of Leicester: PhD Dissertation.

Clark N (2011) Inhuman nature: sociable life on a dynamic planet. London: SAGE.

Correia GFA, Pereira HG and Carrieri AdP (2018) "Ser um ambulante é necessidade que nós temos de trabalhar": cotidiano e identificação de trabalhadores pipoqueiros de Belo Horizonte. Cadernos De Psicologia Social Do Trabalho 21(2): 165-180.

Davies JS and Blanco I (2017) Austerity urbanism: Patterns of neo-liberalisation and resistance in six cities of Spain and the UK. Environment and Planning A 49(7): 1517-1536.

de Certeau M (1984) The Practice of Everyday Life. Berkeley, CA: University of California Press.

de Vries LA and Rosenow D (2015) Opposing the opposition? Binarity and complexity in political resistance. Environment and Planning D: Society and Space 33(6): 1118-1134.

Deleuze G (2006) Foucault. Minneapolis: University of Minnesota Press.

Díaz E (2012) A Filosofia de Michel Foucault. São Paulo: Uniesp.

Farias I (2011) The politics of urban assemblages. City 15: 365-374.

Fleming P and Spicer A (2008) Beyond Power and Resistance: New Approaches to Organizational Politics. Management Communication Quarterly 21(3): 301-309.

Foucault M (1978) The history of sexuality. Vol.1: An introduction. London: Penguin.

Foucault M (1980) Power/knowledge. Selected interviews and other writings, 1972-1977. New York: Pantheon.

Foucault M (1997) The essential works of Michel Foucault, 1954-1984, vol. 1. Ethics, Subjectivity and Truth. New York: The New Press.

Grommé F (2016) Provocation: Technology, resistance and surveillance in public space. Environment and Planning D: Society and Space 34(6): 1007-1024.

Holbraad M, Pedersen MA and Viveiros de Castro E (2014) "The politics of ontology: anthropological positions" Theorizing the Contemporary. Cultural Anthropology Online.

Ju CB and Tang S-Y (2010) External Legitimacy, Goal Congruence and Collective Resistance. Urban Studies 48(4): 811-825.

Junquilho GS, Almeida RAd and Silva ARLd (2012) As "artes do fazer" gestão na escola pública: uma proposta de estudo. Cadernos EBAPE.BR 10: 329-356.

King AD (2010) O que está acontecendo com a pesquisa sobre cidades mundiais? Estudos Históricos (Rio de Janeiro) 23: 247-260.

Kokkinidis G (2014) Spaces of possibilities: workers' self-management in Greece. Organization 22(6): 847-871.

Lauermann J and Vogelpohl A (2019) Fast Activism: Resisting Mobile Policies. Antipode. DOI: 10.1111/anti.12538.

Lees L (2012) The geography of gentrification: Thinking through comparative urbanism. Progress in Human Geography 36(2): 155-171.

Legg S (2018) Subjects of truth: Resisting governmentality in Foucault's 1980s. Environment and 
Planning D: Society and Space 37(1): 27-45.

Limena MMC (2001) Cidades Complexas no Século XXI: ciência, técnica e arte. São Paulo em Perspectiva 15: 37-44.

Machado FCL, Fernandes TA and Silva ARLd (2017) Michel de Certeau e estudios organizacionais: uma leitura do cenário brasileiro. Caderno de Administração 25(2): 24-43.

McFarlane C (2011) Assemblage and critical urban theory. City 15: 204-224.

Özdemir E and Tasan-Kok T (2017) Planners' role in accommodating citizen disagreement: The case of Dutch urban planning. Urban Studies. DOI: 10.1177/0042098017726738.

Papadopoulos D (2011) Alter-ontologies: Towards a constituent politics in technoscience. Social Studies of Science 41(2): 177-201.

Papadopoulos D (2014) Politics of Matter: Justice and Organisation in Technoscience. Social Epistemology: A Journal of Knowledge, Culture and Policy 28(1): 70-85.

Papadopoulos D (2018) Experimental Practice. Technoscience, Alterontologies, and More-Than-Social Movements. Durham, NC: Duke University Press.

Papadopoulos D, Stephenson N and Tsianos V (2008) Escape routes: Control and subversion in the 21st century. London: Pluto Press.

Papadopoulos D and Tsianos V (2013) After citizenship: Autonomy of migration, organisational ontology and mobile commons. Citizenship Studies 17(2): 178-196.

Parker M (2011) Organizing the Circus: The Engineering of Miracles. Organization Studies 32(4): 555569.

Pearsall H (2013) Superfund Me: A Study of Resistance to Gentrification in New York City. Urban Studies 50(11): 2293-2310.

Pinder D (2011) Errant paths: the poetics and politics of walking. Environment and Planning D: Society and Space 29: 672-692.

Rancière J (1998) Disagreement. Politics and philosophy. Minneapolis: University of Minnesota Press.

Routledge P (2009) Resistance. In: Gregory D, Johnston R, Pratt G, et al. (eds) The Dictionary of Human Geography. Hoboken: John Wiley \& Sons, pp.646-647.

Silva CLRd and Silva ARLd (2019) Organization/Sociomaterialidade, Poder e Conexoes em Redes de Acao no Organizar do Artesanato. RAC - Revista de Administracao Contemporanea 23: 454475.

Smith W, Higgins M, Kokkinidis G, et al. (2015) Becoming invisible: The ethics and politics of imperceptibility. Culture and Organization. DOI: 10.1080/14759551.2015.1110584. 1-20.

Spinney J (2010) Performing Resistance? Re-Reading Practices of Urban Cycling on London's South Bank. Environment and Planning A: Economy and Space 42(12): 2914-2937.

Stephenson N and Papadopoulos D (2006) Analysing everyday experience. Social research and political change. London: Palgrave Macmillan.

Swanlund D and Schuurman N (2019) Resisting geosurveillance: A survey of tactics and strategies for spatial privacy. Progress in Human Geography 43(4): 596-610.

Swyngedouw E and Kaika M (2003) The making of 'glocal' urban modernities. City 7: 5-21.

Tolia-Kelly DP (2006) Affect - an ethnocentric encounter? Exploring the 'universalist' imperative of Emotional/affectual geographies. Area 38(2): 213-217.

Tsianos V, Papadopoulos D and Stephenson N (2012) This is class war from above and they are winning it: what is to de done? Rethinking Marxism 24(3): 448-457.

Uitermark J, Duyvendak JW and Kleinhans R (2007) Gentrification as a governmental strategy: social control and social cohesion in Hoogvliet, Rotterdam. Environment and Planning A 39: 125141.

Whitson R (2007) Hidden struggles: spaces of power and resistance in informal work in Argentina. Environment and Planning A 39: 2916-2934.

Wideman TJ and Masuda JR (2018) Toponymic assemblages, resistance, and the politics of planning in Vancouver, Canada. Environment and Planning C: Politics and Space 36(3): 383-402.

Williams A, Cloke P and Thomas S (2012) Co-Constituting Neoliberalism: Faith-Based Organisations, Co-Option, and Resistance in the UK. Environment and Planning A: Economy and Space 44(6): $1479-1501$.

Williams M (2016) Searching for actually existing justice in the city. Urban Studies 54(10): 2217-2231. Wittgenstein L (1958) Philosophical investigations. New York: Prentice Hall. 
Woolgar S and Lezaun J (2013) A turn to ontology in science and technology studies? [Special issue]. Social Studies of Science 43(3): 321-462. 